Teknomekanik

Vol. 4, No. 1, May 2021, pp. 30 35

e-ISSN: 2621-8720 p-ISSN: 2621-9980

\title{
Optimization of Building Energy Consumption in Universitas Negeri Padang Using Building Energy Simulation Program
}

\author{
Andre Kurniawan ${ }^{1}$, Nanang Qosim ${ }^{2}$, Remon Lapisa ${ }^{1}$, Zainal Abadi ${ }^{1}$ and Jasman $^{1}$ \\ ${ }^{1}$ Department of Mechanical Engineering, Faculty of Engineering, Universitas Negeri Padang, Padang 25131, Indonesia \\ ${ }^{2}$ Department of Mechanical Engineering, Politeknik Negeri Malang, Malang 65141, Indonesia
}

\begin{tabular}{|c|c|}
\hline Article Info & ABSTRACT \\
\hline Article history: & Energy consumption of a building is one of the biggest sources of energy use today. \\
\hline $26^{\text {th }} \cdot 2021$ & Green Building Committee Indonesia (GBCI) has launched a concept of energy \\
\hline $29^{\text {th }}, 2021$ & consumption saving in a nationally standard building. Audit Building energy audit \\
\hline Accepted Apr $29^{\text {th }}, 2021$ & $\begin{array}{l}\text { ilding energy consumption is and find alternative } \\
\text { sumption in order to fulfill the energy saving }\end{array}$ \\
\hline & building criteria. Two types of HVAC systems will be run in the Energy Plus \\
\hline Keywords: & $\begin{array}{l}\text { simulation, split } A C \text { and central } A C \text {. The previous research proved that central } A C \\
\text { is better than split } A C \text { system for energy saving in the building with } 20 \text { floors. The }\end{array}$ \\
\hline Building energy consumption & simulation results show that by using a certain energy system, a more efficient \\
\hline Green building & energy system will be achieved and can still maintain the comfort of the room at a \\
\hline Energy Plus & temperature of $24{ }^{\circ} \mathrm{C}$ and relative humidity according to the Green Building \\
\hline Energy saving & Indonesia standard reference. \\
\hline
\end{tabular}

\section{Corresponding Author:}

Andre Kurniawan,

Department of Mechanical Engineering, Faculty of Engineering, Universitas Negeri Padang

Jln. Prof. Dr. Hamka Air Tawar, Padang 25131, Sumatera Barat, Indonesia

Email: andrekurniawan@ft.unp.ac.id

\section{INTRODUCTION}

In today's modern era, one form of environmentally friendly is by doing greening and minimizing the effects of global warming. One of the creative solutions to global warming that has recently been promoted is by applying green buildings [1]. Green building refers to the structure and use of processes that are environmentally responsible and resource-efficient throughout the life cycle of the building from site selection, design, construction, operation, maintenance, renovation and demolition. This practice extends and complements classic building designs in terms of economy, utility, durability and comfort.

For getting green building certification in Indonesia, there are some building requirements including Energy Efficiency Index (EEI) for the last 6 months maximum and temperature control. EEI maximum value for an office is $250 \mathrm{kWh} / \mathrm{m}^{2}$.year [2]. Temperature control value is between $24{ }^{\circ} \mathrm{C}-27^{\circ} \mathrm{C}$ and relative humidity between $55 \%-65 \%$ [3].

In this paper, we present some recommendations in order to fulfill the building criteria as saving energy building based on the result of some simulations. The objective of our study is to develop a few optimization methods to obtain the optimum electrical energy for different techniques such as air conditioning and lighting control. In order to contribute to the green building certification, we used three optimization criteria: cooling energy needs, relative humidity comfort, and cost.

\section{METHODS}

The proposed method is based on the following steps:

- Reduction of simulation time by removing the unnecessary door dan roof;

- Complete building construction data is chosen from EnergyPlus;

- The data on HVAC, lighting, and other equipment used in buildings are getting from Revit;

- Parameters the number of people and occupancy in each area of the building are getting from Revit;

- Thermostatic parameters for the specification of the air conditioning are getting from SNI. 

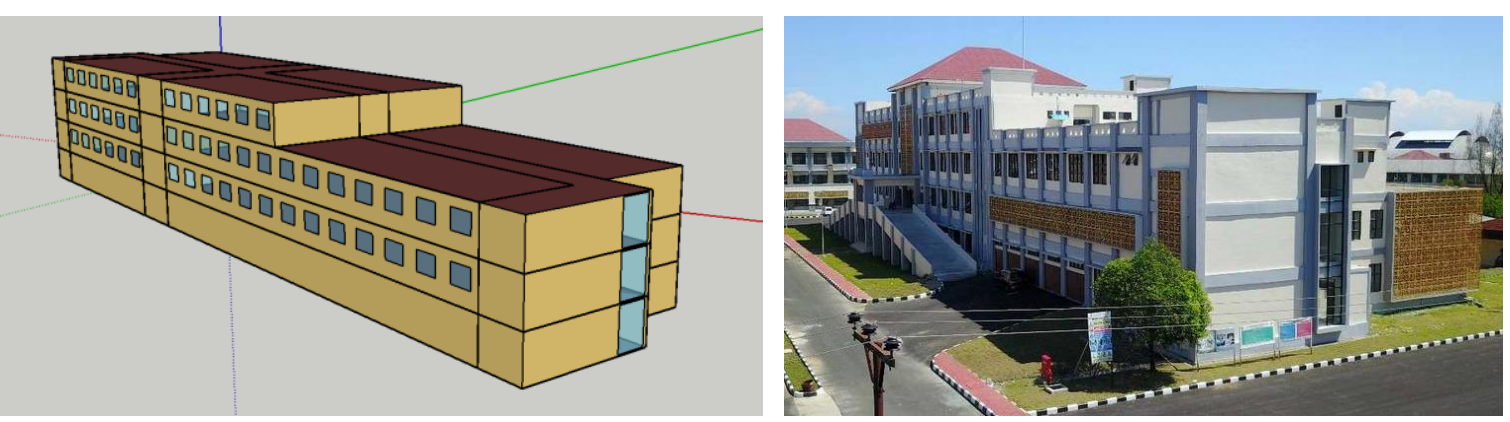

Figure 1 : Schematic views of the building model

\subsection{Case Study and Building Parameters}

The building that will be simulated in this study is already standing and in operation (existing building). This building was built with the aim of being lecturer rooms, staff rooms, and auditorium. This public university engineering faculty building consisting of four floors located in Padang. It is located at $0.898^{\circ}$ latitude and $100.35^{\circ}$ longitude. It is at an altitude of $3 \mathrm{~m}$ above sea level and located at $113^{\circ}$ from the north.

\subsection{People Schedule}

Lighting schedule also depends on the schedule of people attendance. Fig. 2 shows a chart of the people schedule and we used in the EnergyPlus simulation obtained from Revit Autodesk 2020 [4]. There are two different charts is used including on weekdays and Saturday because Saturday is not as busy as weekdays.

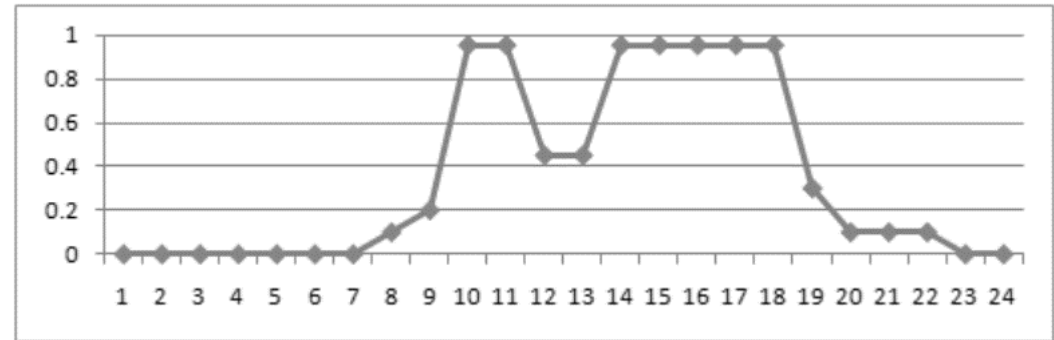

Office schedule on weekdays

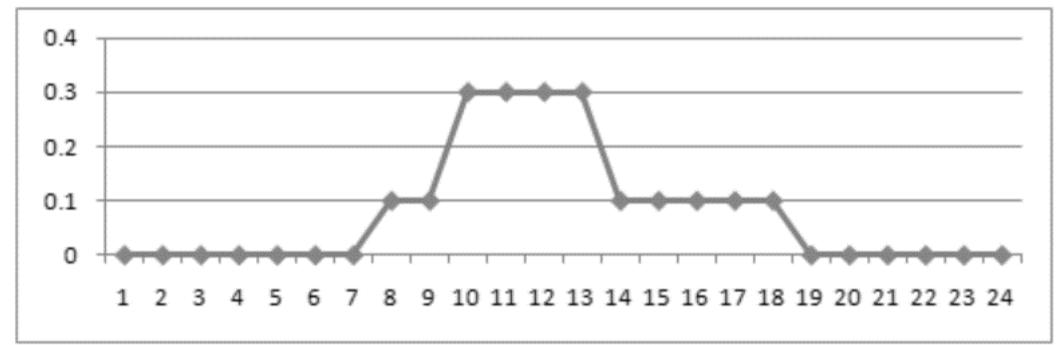

Office schedule on Saturday

Figure 2 : Office schedule from Revit Autodesk 2020

\subsection{Space Type Schedule}

Other things that greatly affect the cooling load are the internal gain of people, lighting, and also the infiltration of air entering the room. For this building, the lighting data used is not yet known, so it is assumed that the building uses lighting according to ASHRAE standards. The following are the indoor standards (Space Type Data) based on ASHRAE obtained from Revit Autodesk [5]. Revit Autodesk also give some other information such as occupancy schedule, power schedule, and must be converted information into the following equation:

1 People/100 sq. M. = 0,01 Person $/ \mathrm{m}^{2}$

$1 \mathrm{~W} / \mathrm{sq}$. ft. $=10,8 \mathrm{~W} / \mathrm{m}^{2}$ 
Table 1: Office type schedule

\begin{tabular}{ll}
\hline Parameter & Value \\
\hline Occupancy schedule & $8 \mathrm{am}-5 \mathrm{pm}$ \\
Power schedule & $6 \mathrm{am}-11 \mathrm{pm}$ \\
People/100 sq. M. & 50.0 \\
People sensible heat gain (Btu/hr.) & 250 \\
People latent heat gain (Btu/hr.) & 200 \\
Lighting load density (W/sq. ft.) & 1 \\
Power load density (W/sq. ft.) & 1.5 \\
Electrical equipment radiant (\%) & 0.3 \\
\hline
\end{tabular}

\subsection{Luminaire Type}

The fraction contained in the light object is obtained from the standard indoor lamp installation [6]. The fraction value depends on the luminaire type of lighting. The following types of luminaire are commonly used.

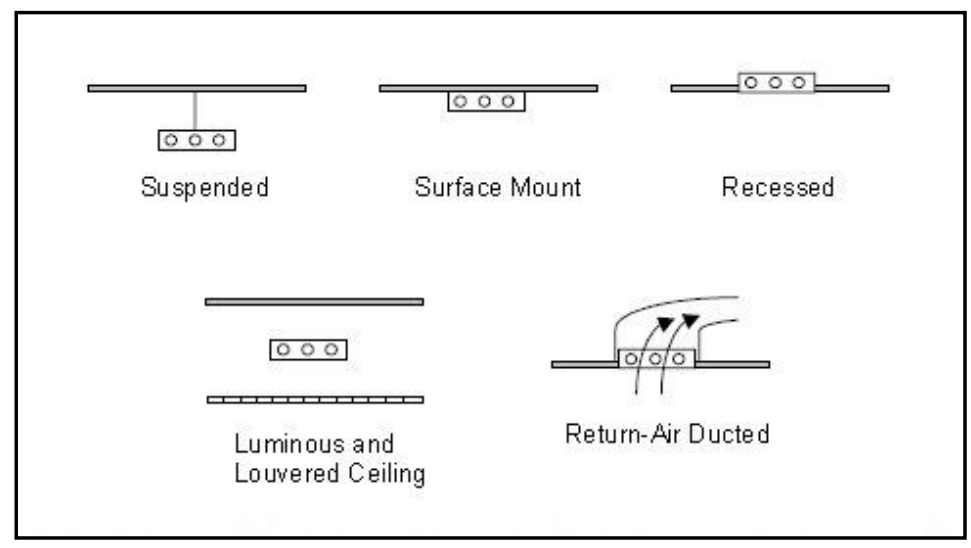

Figure 3: Luminaire type on ceiling

The luminaire type used in buildings is the recessed type (located inside drop celling). And there are four fractions including return air fraction, radiant fraction, visible fraction, and convected fraction. All the value of fraction is used to get lighting configurations.

Table 2: Luminaire configuration

\begin{tabular}{lccccc}
\hline \multirow{2}{*}{ Data } & \multicolumn{6}{c}{ Luminaire Configuration, Fluorescent Lighting } \\
\cline { 2 - 6 } & SP & SM & RC & LL & RA \\
\hline Return Air Fraction & 0,0 & 0,0 & 0,0 & 0,0 & 0,54 \\
Radiant Fraction & 0,42 & 0,72 & 0,37 & 0,37 & 0,18 \\
Visible Fraction & 0,18 & 0,18 & 0,18 & 0,18 & 0,18 \\
Convected Fraction & 0,40 & 0,10 & 0,45 & 0,45 & 0,10 \\
\hline
\end{tabular}

Note:

$\mathrm{SP}=$ Suspended

$\mathrm{SM}=$ Surface Mount

$\mathrm{RC}=$ Recessed

$\mathrm{LL}=$ Luminous and louvered ceiling

$\mathrm{RA}=$ Return-air ducting

\subsection{Temperature Setting (Thermostat)}

The desired working temperature is regulated based on SNI 03-6390-2011 standards [3] concerning energy conservation of building air conditioning systems, namely to meet the thermal comfort of building users, a room temperature of $24^{\circ} \mathrm{C}$ is used. 


\section{RESULTS AND DISCUSSION}

\subsection{Building Utility Performance}

This report presents in detail the use of energy for a period of a year (annual period) and also details the data based on the total area of the building and the area of the building that is conditioned.

Table 3: Building area

\begin{tabular}{lr}
\hline & Area $\left[\mathbf{m}^{2}\right]$ \\
\hline Total building area & 9.173 \\
Conditioned building area & 6.664 \\
Unconditioned building area & 2.509 \\
\hline
\end{tabular}

Unconditioned building area appears because there are some spaces that is not set for lighting and air conditioning system like corridors. The space like that is still drawn in order to keep heat transfer going through between its walls.

Table 4: Energy distribution in the ideal loads air system

\begin{tabular}{lcc}
\hline & Energy/conditioned area $\left[\mathbf{k W h} / \mathbf{m}^{\mathbf{2}}\right]$ & Energy/total area $\left[\mathbf{k W h} / \mathbf{m}^{\mathbf{2}}\right]$ \\
\hline Lighting & 45 & 32,69 \\
HVAC & District cooling 244,35 & District cooling 177,51 \\
Total & 289,35 & 210,2 \\
\hline
\end{tabular}

In the table above, in HVAC there are two possible districts will be shown. There are heating district and cooling district. Because Padang is one of the cities in a tropical country, Indonesia, no heating will be required.

\subsection{Comparing AC System}

By comparing the results obtained from the simulation results in the following table, it can be seen that by using the unitary cooling system, the total energy used is 1,902.1 MWh, while by using the VAV system the total energy use is 3,636.5 MWh.

Table 5: Energy distribution in the unitary and VAV system

\begin{tabular}{|c|c|c|c|c|}
\hline & \multicolumn{2}{|c|}{ Unitary System $\left[\mathrm{kWh} / \mathrm{m}^{2}\right]$} & \multicolumn{2}{|c|}{ VAV System [kWh/m²] } \\
\hline & $\begin{array}{c}\text { Energy/ total } \\
\text { area }\end{array}$ & $\begin{array}{c}\text { Energy/ } \\
\text { conditioned area }\end{array}$ & $\begin{array}{l}\text { Energy/ total } \\
\text { area }\end{array}$ & $\begin{array}{c}\text { Energy/ } \\
\text { conditioned area }\end{array}$ \\
\hline Lighting & 32,69 & 45,00 & 32,69 & 45,00 \\
\hline HVAC & 174,67 & 240,43 & 363,75 & 500,70 \\
\hline Total & 207,36 & 285,43 & 396,44 & 545,69 \\
\hline Total Energy & 1.902 &, $1 \mathrm{MWh}$ & 3.636 & $5 \mathrm{MWh}$ \\
\hline
\end{tabular}

The energy consumption is the sum of the building's energy consumption, which consists of lighting and air conditioning. The distribution of energy consumption can be divided by Energy Plus based on the total area of the building and also the area that is conditioned. From the simulation data table above, it can be said that energy consumption will be lower by using the unitary system (split air conditioning) compared to the VAV system (central air conditioning).

Table 6: Differences in energy consumption of each cooling system

\begin{tabular}{lrr}
\hline & Unitary system & VAV system \\
\hline Total energy $(\mathrm{MWh})$ & 1.902 & $3.636,5$ \\
Energy/total area $\left(\mathrm{kWh} / \mathrm{m}^{2}\right)$ & 207,36 & 396,44 \\
Energy/conditioned area $\left(\mathrm{kWh} / \mathrm{m}^{2}\right)$ & 285,43 & 545,69 \\
Electricity cooling $(\mathrm{MWh})$ & $1.318,65$ & $2.577,96$ \\
Electricity interior lighting (MWh) & 299,86 & 299,86 \\
Electricity fans (MWh) & 283,56 & 205,33 \\
Electricity pumps $(\mathrm{MWh})$ & 0 & 495,45 \\
Electricity heat rejection $(\mathrm{MWh})$ & 0 & 57,91 \\
\hline
\end{tabular}


In the table above, it is clear that the difference between the two systems is seen from the use of energy (electrical energy) during a period of one year. The use of electrical energy is divided into several main components, namely energy for lighting and energy for air cooling. The energy for lighting is the same for the two systems used, but different for air cooling energy. Energy for cooling the air using the unitary system is 1,318.5 MWh and using the VAV system is 2,577.96 MWh.

From the table it can also be seen that the lowest total energy use is using the unitary system about 1,902 MWh, while for the VAV system about 3,636.5 MWh. With this value, it can be concluded that the unitary system is more efficient for this building cooling system. Based on the requirements for energy-efficient buildings in accordance with the criteria of the Green Building Council Indonesia, this building does not meet the requirements either if it uses the unitary air conditioning system or the VAV system. When viewed from the energy per area conditioned by the unitary system is $285.43 \mathrm{kWh} / \mathrm{m}^{2}$. While the criteria from the Green Building Council Indonesia for office or school buildings are $250 \mathrm{kWh} / \mathrm{m}^{2}$.

\subsection{Optimization Method Using Daylighting Control}

The conditioned zone is given an illuminance setting (lighting) of 500 lux for one point per zone where there are up to 10 points that can be positioned in a zone. Meanwhile, there are 3 types of daylighting control used to complete the simulation of the unitary system template, namely the lighting control type: continuous, continuous-off, and stepped [7]. The following table shows the simulation results of the unitary system template using the three types of daylighting control.

Table 7: Differences in energy consumption of each cooling system

\begin{tabular}{lrrrr}
\hline \multirow{2}{*}{ System } & \multirow{2}{*}{ With no DC } & \multicolumn{3}{c}{ Using daylighting control } \\
\cline { 3 - 5 } & & Cont & ContOff & Stepped \\
\hline Total site energy $(\mathrm{MWh})$ & $1.902,1$ & $1.796,3$ & 1.766 & $1.817,97$ \\
EPCA $\left(\mathrm{kWh} / \mathrm{m}^{2}\right)$ & 285,43 & 269,56 & 265,02 & 272,8 \\
Cooling $(\mathrm{MWh})$ & $1.318,65$ & $1.300,7$ & $1.295,5$ & $1.305,8$ \\
Lighting (MWh) & 299,86 & 212,45 & 187,4 & 228,6 \\
\hline
\end{tabular}

We compare the energy per conditioned area (EPCA) in four cases (with no daylighting control, using continuous, continuous-off, and stepped daylighting control). Fig. 4 dan Fig. 5 shows the effect of using daylighting control on the cooling and lighting energy consumption.

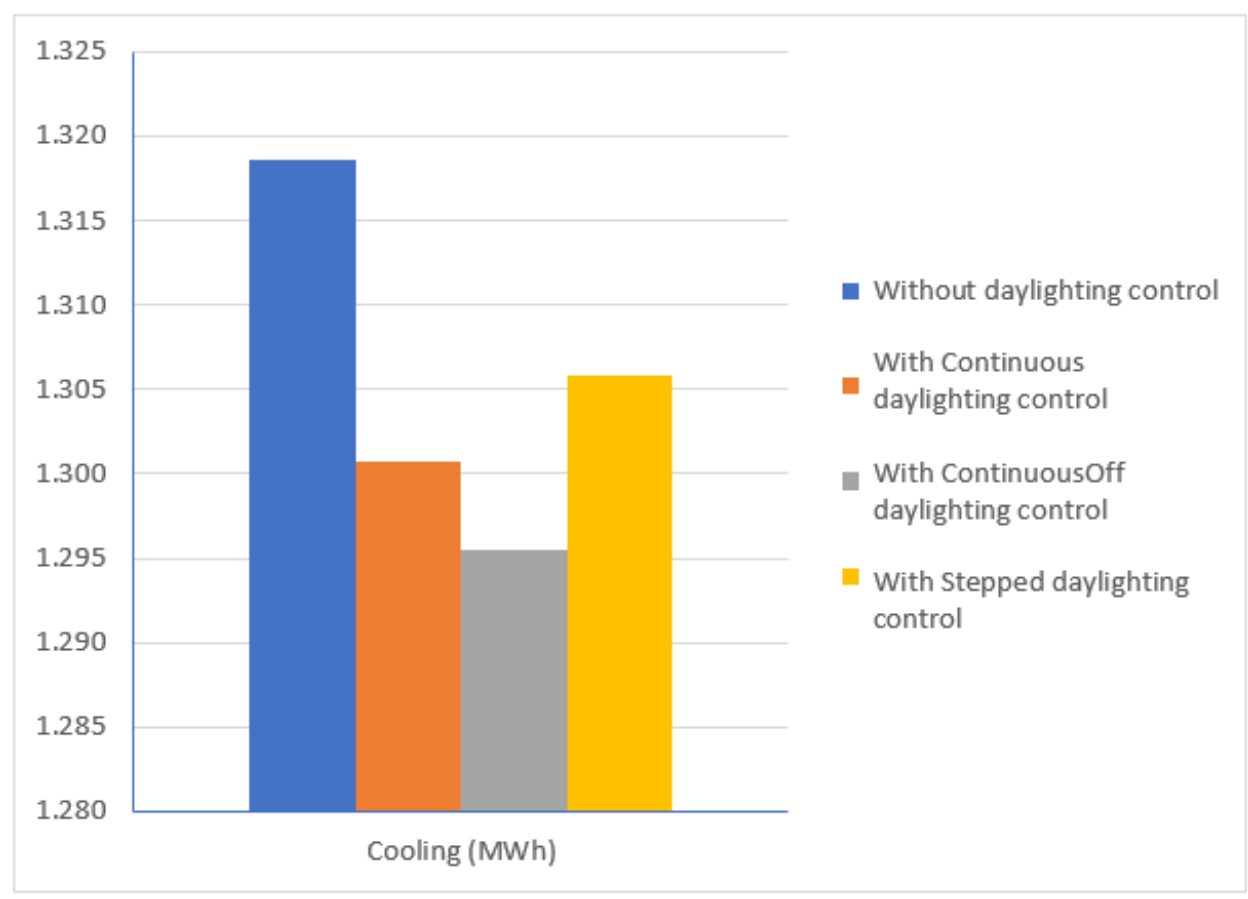

Figure 4: Effect of daylighting control on cooling energy 


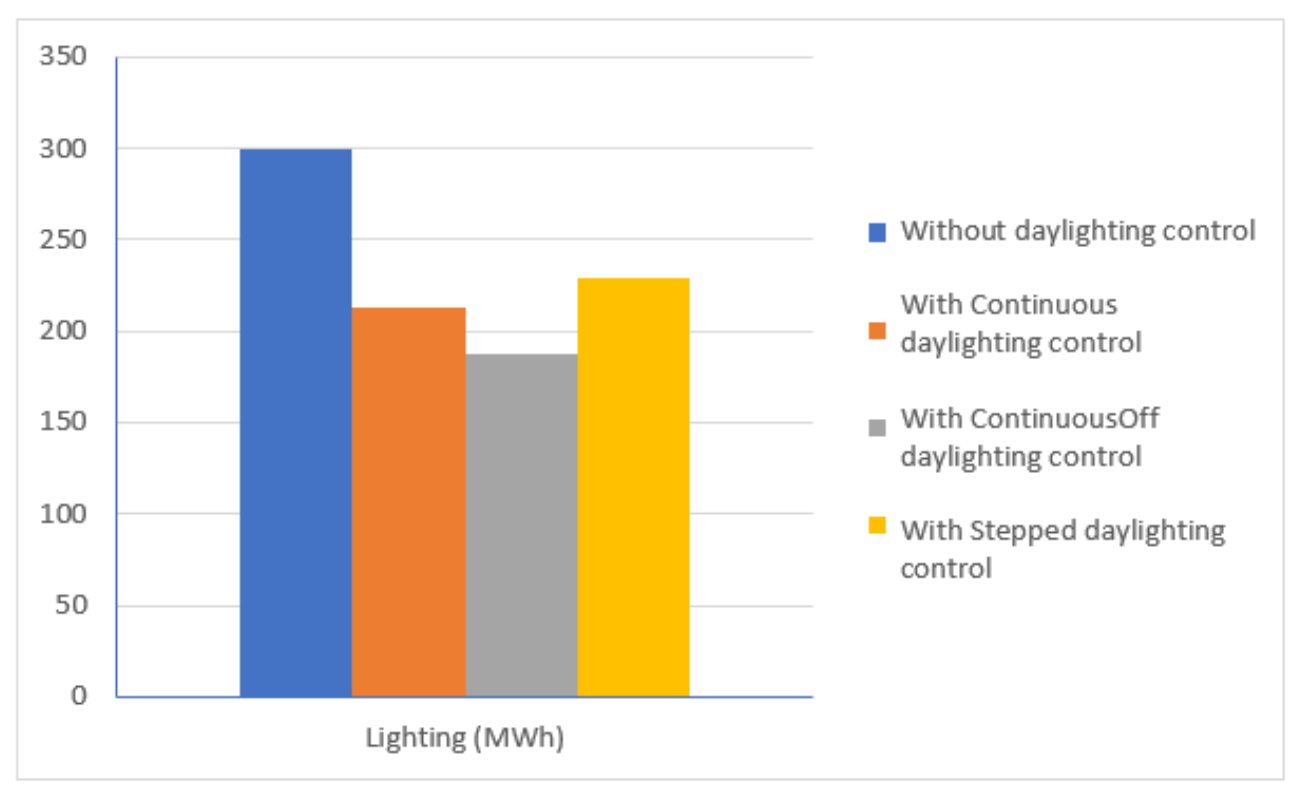

Figure 5: Effect of daylighting control on lighting energy

\section{CONCLUSION}

Based on the simulation results with the addition of daylighting control, it can be seen that there is not only a decrease in energy consumption in lighting but also in air cooling. This happens because the intensity of lighting also affects the increase in thermal heat in the room (internal gain). Thus, it can be recommended to use the most efficient air conditioning system for this building in the form of a unitary system or split air conditioning type which is commonly used and can be further optimized by adding a Continuous Off type of daylighting control in some conditioned rooms.

\section{ACKNOWLEDGEMENTS}

The authors would like to thank Lembaga Penelitian dan Pengabdian Masyarakat Universitas Negeri Padang for funding this work with a contract number: 1348/UN35.13/LT/2020.

\section{REFERENCES}

[1] P. H. Shaikh, M. S. Shaikh, M. Kumar, F. Shaikh, M. A. Uqaili, and I. Bhatti, "Environmental Assessment of Green Buildings," in Encyclopedia of Renewable and Sustainable Materials, Elsevier, 2019, pp. 92-97.

[2] Green Building Council Indonesia, Greenship Existing Building, Version 1. Jakarta, 2011.

[3] Badan Standarisasi Nasional, SNI 03-6390-2011: Konservasi Energi Sistem Tata Udara pada Bangunan Gedung. Jakarta: Dewan Standarisasi Indonesia, 2011.

[4] Autodesk, Occupancy Schedules. 2020.

[5] Autodesk, Space Type Data for Energy Analysis. 2020.

[6] DesignBuilder, General Lighting. 2020.

[7] Big Ladder Software, "Daylighting Control," 2020, [Online]. Available: https://bigladdersoftware.com/epx/docs/8-0/input-output-reference/page-016.html. 